\title{
An Integrated Reading/Writing Instruction for Better EFL Trainees at the Teachers Training School of Constantine (ENSC)
}

\begin{abstract}
:
Several studies acknowledge the importance of integrating reading and writing in one subject but few EFL contexts seem to consider this claim. Teachers Training School of Constantine (ENSC), Algeria, is a standing case where these two language skills are till nowadays taught as discrete subjects neglecting new ways of a more meaningful learning. This paper reports the findings of an empirical study which investigates the impact of the implementation of an integrated reading/writing instruction through the use of reading response journals (RRJs) on trainees' achievements in these two skills. An experimental design is used where a treatment intervention is applied preceded by a pretest and followed by a posttest. A quantitative analysis is conducted confirming that teaching EFL reading and writing in an integrated way through RRJs helped enhance trainees' level in both skills.
\end{abstract}

$$
\begin{aligned}
& \text { لخص: } \\
& \text { على الرّّم من أن عدد كبير من الأبحاث يدعو الى دمج } \\
& \text { تدريس القر اعة و الكتابة كمادة واحدة ماز ال فصلهما هو التقليد } \\
& \text { السائد في قسم اللغة الإنجليزية بالمدرسة العليا لتكوين الأساتذة } \\
& \text { بقسنطينة . هذا المقال يهدف الى عرض نتائج در اسة تجريبيّة } \\
& \text { اعتمدت منهجية الدمج بين القراءة و الكتابة باللغة الإنجليزية } \\
& \text { كلغة أجنبية لمدة فصل در اسي كامل مبيّنة ارتفاع ملموس فى } \\
& \text { تحصيل الطلاب فى كلتا المادتين مقارنة بمستوى الطلاب } \\
& \text { اللّذين لم يشاركوا في التجربة. اعتمادا على هذه النتائج } \\
& \text { الإيجابية ، يقدم المقال مقترحات أوّلية لتبني منهجية دمج } \\
& \text { تدريس القر اءة و الكتابة فى مقياس و احد. }
\end{aligned}
$$

\section{LABIOD Ahlem}

Faculté des Lettres et des Langues.

Département d'Anglais. Université Larbi Ben M'hidi - Oum El Bouaghi.

\section{Introduction:}

Although recent research both in theory and practice stresses the importance of integrating reading and writing in one instruction and divorcing the traditional segregation between these skills, a number of EFL contexts including the Teachers Training School of Constantine (ENSC) continues to clash with these directions. 
Arciuli (2009: 633) argues that reading and writing are the two skills which allow human species to prosper since they boost their cognitive capacities. To that end and as teachers, helping learners overcome their difficulties with these skills should receive full attention. In fact, first, second and third-year students of English at ENSC are still having reading and writing as two discrete subjects, namely reading techniques and written expression, and no direct attempt is made towards any form of integration. Therefore and through this paper, the aim is to shed light on the reading and writing connections and to attempt their integration so that the EFL classroom takes advantage of their complimentary nature. This article gives a brief review of previous related literature, discusses the reading writing connection, defines integrated reading/writing instruction, shows its objectives and strategies and presents one exemplary integrated instruction. Then, an experimental pretest/posttest methodological design provides quantitative analysis of results, discussion and conclusion.

\section{Theoretical and Empirical Framework}

By the 80 's, and with the shift from psychological studies to social communicative ones, reading and writing started to be viewed as context-based social events instead of isolated skills each taught separately. The interwoven nature of reading and writing is stressed by a number of studies which tackled it from different angles. Krashen (1985: 23), in his studies about second language acquisition, suggests that language acquisition is the result of long time exposure to an input and thus acquiring writing is a matter of long time exposure to a reading input and not just extra practice of writing. Stotsky (1983) summarizes the results of some empirical works through which she attempts to figure out the extent of correlation existing between reading and writing. Her valuable correlation studies reveal that "better writers tend to be better readers (of their own writing as well as of other reading material), that better writers tend to read more than poorer writers, and that better readers tend to produce more syntactically mature writing than poorer readers" (636). Some literacy research works poured out views about the shared similarities between reading and writing. Kucer (2009: 8) claims that reading and writing should not be reduced to single -based disciplines since they are part of a dimensional literacy act which draws from different language aspects being linguistic, cognitive, socio-cultural and developmental. Grabe (1991: 394) insists that reading and writing are related in terms of being skills, in terms of the cognitive processes involved in them and in terms of their ways of learning.

Other research studies on reading/writing integration are divided into categories according to their investigation focus. Zhou \& Siriyothin ( 2009: 298) report this division and provide examples of researchers as follows: studies stressing the influence of reading on writing ( Tsang, 1996; Hirvela, 
2004); studies examining the correlation between reading and writing (Tierney \& pearson, 1983; Carson, Many, et all., 1996; Olson, 2003) and studies questioning the theoretical explanations of the relationships between reading and writing ( Kuccer, 1987; McCarthy, 2001; Esmaeili, 2002; Carson, 2004; Grabe, 2004; Jabbour, 2004; Smagorinksy, et al., 2005; Parkinson, et al., 2007). In addition, Graham \& Herbet (2010: 4) report about research studies stressing other points of focus. First, Fitzgerald \& Shanahan (2000) investigate the functional combination between reading and writing. Second, Shanahan (2006) studies reading and writing shared knowledge and cognitive processes. Third, Tierney\& Shanahan (1991) studies provide evidence about the following questions: 1) Does writing about material students read enhance their reading comprehension? 2) Does teaching writing strengthen students' reading skills? 3) Does increasing how much students write improve how well they read? Indeed, this large number of research works is the motor pushing our interest to stress the importance of the interdependent relationship between reading and writing in the EFL context of the Teacher Training School of Constantine.

\section{Reading and Writing: Two Faces of the Same Coin}

Reading and writing are two faces of the same coin; each has common and shared aspects with the other. This entails that there is a large number of similarities between reading and writing. Lems et al. (2010:193) provide a summary of the most significant shared aspects. First, stress falls on the linguistic or language shared knowledge; both of them use language and require linguistic competence. For example, phonemes, graphemes, vocabulary, grammar, syntax and punctuation are a common linguistic storage the reader as well as the writer draws from. Second, strategic knowledge is another shared aspect; both skills require students to use strategies like using brainstorming before reading and writing. Third, common social and cultural knowledge is also another connection to point to. For instance, both skills have a communicative purpose for a particular audience with certain cultural considerations. Fourth, discourse knowledge is also an addressed similarity. In other words, readers and writers are confronted to the fact that reading and writing have a discourse mode which is different from oral language and they are as well exposed to different rhetorical genres hence different organizations and structures. Fifth, both skills use complex cognitive operations; creating meaning, organizing and storing information and then retrieval from memory stock. Finally, both of reading and writing help in academic success and consequently foster thinking and push personal and social growth.

\section{Integrated Reading/Writing Instruction}

Integrated Reading/writing instruction is defined as an instruction wherein the teaching of reading and writing is melt through the use of combined 


\section{LABIOD Ahlem}

classroom activities through which learners develop awareness about the convergences existing between these two processes. This definition is similar to what Kurland and Rohr (2009: 1) state: " 1) a method of teaching wherein the similarities and connections between reading and writing are made explicit to the learner .2) A course in which students are made to see how the structures, practices and language of each process can enhance understanding of the other."From this definition, we deduce that the objectives of this instruction center on the following points: the first objective is to put emphasis on reading and writing as purposeful skills. The second desire is to reach the point of stressing literacy improvement rather than a purely separated teaching of reading and writing. The third one is to give importance to using the existing connection and transaction between the two processes. Finally, and as a result of these three objectives, learners will be encouraged to develop an independent mastery and control of their learning processes of both reading and writing after developing a new conception of the union or convergences relating the two skills.

To reach these objectives and ensure successful integrated reading/writing instruction, the profile of teachers who are decision makers in their classrooms needs to be discussed. A common course relating the two skills needs an EFL reading/writing instructor; a teacher of both reading and writing with a teaching philosophy encouraging this integrated approach. On this profile, Gambrell et al. (2007: 17) give a list of qualities of knowledge required in the integrated reading/writing instructor:

- Declarative knowledge: knowing "what works" the evidence-based best practices for comprehensive literacy instruction.

- Procedural knowledge: knowing how the best practices are implemented.

- Conditional knowledge: knowing when a particular practice is preferable to another.

- Reflective knowledge: knowing when a practice is working effectively, or not.

- Adaptive knowledge: knowing how to combine or adapt practices or techniques to meet the needs of particular groups of students or individuals.

If the profile of reading/writing instructor matches the needed knowledge and the objectives of reading/writing course are respected, the implementation will be easy. This entails that the instructor and instead of working on traditional classroom activities moves to adopt or adapt integrated reading/writing classroom practices matching the objectives and goals of the course and using the adequate strategies.

\subsection{Integrated Reading /Writing Strategies}


Integrated reading/writing instruction is better presented if light is shed on the used integrated strategies. These strategies are all what can make the connection between the two processes possible. Kurland and Rohr (2009: 1) give a list of effective strategies helping in integrating reading and writing in one instruction:

- Use KWL+ as a heuristic to initially explore both writing and reading.

- Teach TEA (Topic/Evidence/Analysis) as a method for encouraging students to understand the development and organization of both the texts they read and the texts they write.

- Alter the traditional 'reading to write' paradigm by also promoting 'writing to read' activities to activate and assess schema and increase comprehension.

- Reinforce the dialogical nature of reading and the reciprocity of both reading and writing as conversational in nature through the use of multi-entry journals.

- Promote extensive reading as a means of alerting students to the multiple purposes and benefits of reading.

- Make vocabulary learning an integral component of the classroom through the use of a vocabulary and collocations log.

These strategies and mainly others are used in the integrated reading/writing instruction to help learners improve their achievements in both skills. According to the above list, these activities fall under the read-to write or writeto read paradigms where the teacher tries to alternate them along his session time. A variety of tasks can fulfill the objective of linking reading and writing in one activity. For instance, the teacher may assign "a read and then summarize" activity to achieve the "read-to write" objective as he can teach "summary skills" to develop the skill of synthesis in reading achieving, the "write-to read" aim. Moreover, it is important from the part of the teacher to respect the criteria of effective classroom activities. That is to say, any activity inside or outside the classroom should match learners' level, respect the time allocated for it, precise the best material to be used, define clearly the procedure to be followed and determine criteria of comments and evaluation by the end of the task. If the teacher takes account of all these elements, most likely he is to honor the objectives of such activity.

\subsection{RRJs as an Exemplary Practice of Integrated Reading/Writing Instruction}

Journaling is a multifaceted activity where reading/writing integration is put into a permanent exercise. Blachowicz \& Ogle (2008: 5) define reading response journals as tools through which learners record their feelings and responses as reactions to their reading experiences sometimes in a totally free 
way and other times directed by teachers' inspiring prompts. The heart of this practice is students' use of all types of linguistic, cognitive, affective and social free responses with no frustration of the quality of the idea or the correctness and appropriateness of the language. On the same line of thought, Silberstein (1994: 98) adds that RRJs are characterized by a free composition about extensive reading experiences where correctness of the language or the quality of the idea are not centralized since grading and evaluation are not stressed in this practice.

This integrated reading/writing practice is based on two main theories. First, Rosenblatt's (1988: 5) transactional theory which stresses the notion of "stance". For her and because of the transactional nature of reading and writing, the reader must have an efferent stance as well as an aesthetic one. Similarly, the writer constructs meaning not just on the grounds of his linguistic reservoir but draws also from his experiential and affective storage. Besides, RRJs import from the reader response-theory which is of influence in determining the efficacy of the communicative act through reading and writing. Carlisle (2000: 12) argues that "the active and communicative nature of the reader-response theory suggests it would complement other modern trends in ELT". As its origins are in the field of literary criticism, it asserts supremacy to the different possible text interpretations (Hirvela, 1996: 128). This means that the meaning contained in a text is interpreted differently from one reader to another and thus writers' awareness about this fact helps them construct texts with a wide vision of audience considerations accounting for sex, race, political and religious identities.

RRJs do not have one unique form or one fixed type. The reading/writing instructor or learners are the ones to form or give particular shape to the journal in accordance to the rationale adopted. Dowrick, S. (2009: 3) states: "every journal is inevitably original. When it comes to journal writing, there is no formula. There are certainly props and prompts". That is to say, there is no exact shape or form to be applied for all reading response journals. For example, if the instructor is requiring learners to compare two characters in the story, the journal may have a certain form suiting the comparison prompt but if he is asking them to pick up a quote and then provide personal comments about it, the journal will take another form. Therefore, the form or type of the journal is dictated by the type of the prompt either provided by the teacher or simply a personal one.

Although RRJs take different forms, they share the same rationale or philosophy of application. Ming-Yue (2009: 92) reports about its simplest application and easiest procedure which will be the one adopted in this research work. Simply, the RRJ is a notebook where learners record responses about weekly reading assignments. These reading assignments vary between novels, short stories, poems, or expository texts. Responses produced by learners are 
stimulated by prompts given by the instructor or simply by learners themselves. Each prompt constitutes what is called the journal entry. For example, the prompt "who is your favorite character in the story? and why?" constitutes one journal entry according to which the learners give their different responses. The journals will be collected weekly and then the instructor comments and gives feedback.

This study opts for RRJs as an exemplary practice of the implementation of an integrated reading/writing instruction because it shows clearly the link existing between the two skills. It is argued that RRJs is a practice which aids the integration of reading and writing and serves as a bridge to connect these two language skills (Silberstein, 1994: 98; Evans, 2007: 240). In addition to combining reading and writing at the same time in one task, it is a means to reduce the "the traditional obsession with the product - with skills, techniques and conventions" (Rosenblatt, 1988: 12) In fact, and through this activity, the student will read and write in a continuous and parallel way profiting from a more meaningful learning of these two language skills.

\section{Why Implementing an Integrated Reading/Writing Instruction in ENSC, Algeria?}

The general scene in the EFL reading or writing classes in ENSC, Algeria, is a traditional one. For the reading course, a prevailing description goes online with "reading experience is often equivalent to one long comprehension exercise "(Carlisle, 2000: 13). For the writing subject, the classroom is a space where trainees struggle to produce compositions and then receive feedback to move on to other weekly productions. No connection between the two skills is made, neither in theory nor in practice. Teachers never come to understand why extra composition practice does not give the right fruit nor do trainees grow in time of practice to start loving writing and thus perform better. Similarly, teachers still find it dreamy to see their trainees hooked by books or at least land at advanced levels of comprehension. Being a teacher who experienced the teaching of these two separate subjects for a number of years, It was noticed that trainees with a low writing proficiency do not have the profile of good readers and vice versa. Trying to help particular struggling students, attempts were usually directed towards stressing the importance of each skill in the enhancement of the other noticing an improvement for learners who resort to the suggested integrated activities. Thus, the objective of this study is to try the integration of reading and writing in one classroom instruction through RRJs as one probable solution to enhance trainees' achievements in these skills and therefore boost their EFL learning.

\section{Methodology}

The study hypothesizes that the implementation of an integrated reading/writing instruction through RRJs is likely to increase third-year EFL 


\section{LABIOD Ahlem}

trainees' reading and writing gained scores. To investigate this hypothesis, an experimental design is used.

The target population is ninety six (96) third-year English language learners at ENSC among which forty four (44) students are randomly selected to participate in the study. This sample of participants is divided randomly into control and experimental groups each consisting of twenty two (22) subjects. The choice of third-year students as a target population is due to a number of reasons. First, these learners were introduced to the "Reading Techniques" module in their first and second years of training. They are by now knowledgeable about all reading skills, strategies, text genres and different comprehension measurement tasks. In addition, learners were introduced to "Written Expression" session for two years also, through which they gained all the writing skills and mechanics passing from, sentence, to paragraph, to expository essay writing and narrative/descriptive composition. Therefore, third-year students are supposed to have the adequate linguistic, strategic and cognitive competences that suit the research question.

\subsection{Pretest}

The experiment started with a pretest of both reading achievement (RA) and writing achievement (WA) of the control group (CG) and the experimental group (EG). The reading achievement pretest was meant to test learners' reading ability prior to the experiment and the writing achievement pretest was supposed to test learners' writing ability before any intervention.

Reading achievement pretest intended to show to what extent learners comprehend the reading material at hand. This test was composed of two parts. In part one, learners read an expository text and in part two they read a literary selection. Both readings were followed by ten (10) true/false comprehension statements. This test was marked on twenty (20) points; ten (10) points for the first part and ten (10) points for the second part. The test was administered by the researcher and one of his colleagues and the time devoted for it was an hour.

Writing achievement pretest was supposed to reveal the extent to which students are able to well compose essays. This writing test was also composed of two parts. In part one, students were required to write an expository essay about an assigned topic. In part two, students were instructed to compose a narrative essay about an assigned topic. The test was marked on twenty (20) points; ten (10) points for each part and it was administered by the researcher and one of his colleagues and evaluated by two writing instructors. The time devoted for the writing test was 3 hours.

\subsection{Treatment}


For twelve (12) weeks, the EG studied reading and writing in separation in addition to receiving the study treatment which was the implementation of an integrated reading/writing instruction through the use of RRJs. However, the CG continued to study reading and writing with no additional intervention which integrates them.

The use of reading response journals was based on two procedures which are the reading procedure and the writing procedure. For the reading procedure, learners were required to read three (3) novels, three (3) short stories, and six (6) expository texts. These reading selections were not the obligation of the researcher but motivation-based lists provided by learners themselves relying on the researcher suggestions for each genre. After every learner ticked his reading choices, the researcher prepared the reading motivation-based sheet for the whole group and put a weekly time schedule for the whole experiment alternating text genres. Reading took place outside the classroom and it was for the researcher to provide learners with a hard copy and an electronic one for all these selections to ease learners' work.

For the writing procedure, learners were provided by other materials. First, an example of the reading response journal sheet which learners were supposed to take and hand back each week was introduced with some explanations. Then and along the experiment period, learners were given RRJs empty sheets in order to respect the form of the journal and not to be bothered by searching on what to write. In addition to this, trainees were helped by a list of prompts and starting words to start their journals. Students were required to write on their journals three thoughtful free responses for each weekly reading selection.

\subsection{Posttest}

After twelve (12) weeks, the CG and EG sat for a posttest in both reading and writing. The posttests respected the same design of the pretests. The reading achievement (RA) posttest was also composed of two parts as follows: part one was devoted to reading an expository text and part two was based on reading a narrative piece. Each reading part was followed by ten (10) true/false statements. The RA posttest was marked on twenty (20) points; ten (10) points for each part. The time allocated for both parts of this posttest was an hour and it was marked by the researcher himself.

Writing achievement posttest was built accordingly to have the same shape of the reading achievement posttest. It has two parts; the expository writing and the narrative one. Learners in the expository part were supposed to write an expository essay and in the narrative part they were required to produce a narrative production. The two parts were marked on twenty (20) points; ten (10) points for each part. Topics in the two parts were assigned and the time allocated for the test was three hours. 


\section{LABIOD Ahlem}

Learners' expository and narrative essays in the pretests and posttests are evaluated and marked by the same two writing instructors using the same marking scheme. This latter considers five factors of evaluation which are content, organization, mechanics, grammar and style. Marks are attributed according to learners' achievement levels as follows: outstanding (10 points), excellent ( 9 points), very good ( 8 points), good (7 points), satisfactory (6 points), sufficient (5 points), insufficient (4 points) and unsatisfactory ( from 3 points to 1 point). The marking scheme provides detailed explanations of the five factors of evaluation and gives sufficient descriptions for each achievement level.

\section{Results and Discussion}

The scores obtained out of the total score of 20 in the pretests and posttests in reading and writing are computed, compared and analyzed quantitatively. The student one-tailed t-test is used to check statistically the results' significance. The latter tests the null hypothesis $(\mathrm{H} 0)$ which supposes that there is no difference between CG and EG mean scores. If the null hypothesis is rejected, the alternative one (HA) which assumes that the mean scores obtained by the EG are significantly higher than those of the CG, will be considered. Qualitative interpretations are beyond the scope of this article.

\subsection{Descriptive Statistics}

\subsubsection{RA Descriptive Statistics}

The table below shows learners' RA in the pretest and posttest for both the CG and EG:

\begin{tabular}{|c|c|c|c|c|}
\hline \multirow{2}{*}{ Statistics } & \multicolumn{2}{|c|}{ CG } & \multicolumn{2}{c|}{ EG } \\
\cline { 2 - 5 } & RA Pretest & RA Posttest & RA Pretest & RA Posttest \\
\hline N & 22 & 22 & 22 & 22 \\
\hline Mean & 11.68 & 12.59 & 11.95 & 16.27 \\
\hline SD & 2.80 & 1.84 & 2.40 & 1.67 \\
\hline Median & 12 & 13 & 11 & 16.5 \\
\hline MIN & 6 & 9 & 7 & 12 \\
\hline MAX & 17 & 16 & 16 & 18 \\
\hline
\end{tabular}

Table 1: Descriptive Statistics: RA pretest and posttest for CG and EG

From Table1, we notice that the mean scores of the CG, 11.68 and EG, 11.95 in RA pretest, are nearly similar with a slight difference. The same remark is made for the rest of values namely standard deviation (SD) and the minimum and maximum scores. However, comparing the means of both groups in RA posttest shows that the experimental mean, 16.27 is interestingly higher than 
the control one, 12.59 with a remarkable difference. An apparent variance is also observed for the remaining values. This initial comparison of RA needs statistical testing to show its significance.

The following table sums up differences in reading gains and the student $t$ test results:

\begin{tabular}{|l|c|c|c|c|c|c|c|}
\hline & \multicolumn{6}{|c|}{ RA Mean differences between CG and EG } \\
\cline { 2 - 8 } & $\mathbf{N}$ & Mean & $\begin{array}{c}\text { Std. } \\
\text { error }\end{array}$ & $\begin{array}{c}\text { std. } \\
\text { deviation }\end{array}$ & $\begin{array}{c}\text { Student- } \\
\text { t }\end{array}$ & DF & $\begin{array}{c}\text { Sig. (p- } \\
\text { value) }\end{array}$ \\
\hline Pretest & 22 & $\mathbf{0 . 2 7}$ & 0.786 & 2.581 & $\mathbf{0 . 3 4 6}$ & 42 & $\mathbf{0 . 3 6 5}$ \\
\hline Posttest & 22 & $\mathbf{3 . 6 8}$ & 0.529 & 2.546 & $\mathbf{6 . 9 4 9}$ & 42 & $\mathbf{0 . 0 0 0}$ \\
\hline
\end{tabular}

Table 2: RA Mean Differences between CG and EG in Pretest and Posttest

Table 2 reveals that RA pretest mean difference between the CG and EG is 0.27 . The standard error of this mean difference is 0.78 and its standard deviation is 2.58 . The t-statistic obtained from the t-test with $42 \mathrm{DF}$ is 0.34 . This value is very low indicating that RA pretest mean difference between the experimental and control subjects is statistically not significant as shown by the corresponding $\mathrm{p}$-value of 0.36 which is very far from 0.05 standard risk level. However, RA posttest mean difference between the CG and EG is 3.68. The standard error of this mean difference is 0.52 and its standard deviation is 2.54 . The t-statistic with $42 \mathrm{DF}$ is 6.94 indicating that RA posttest mean difference between the CG and EG is highly significant at 0.01 risk level.

\subsubsection{WA Descriptive Statistics}

The table below shows learners' WA in the pretest and posttest for both the $\mathrm{CG}$ and $\mathrm{EG}$ :

\begin{tabular}{|c|c|c|c|c|}
\hline \multirow{2}{*}{ Statistics } & \multicolumn{2}{|c|}{ CG } & \multicolumn{2}{c|}{ EG } \\
\cline { 2 - 5 } & WA pretest & WA posttest & WA pretest & WA posttest \\
\hline N & 22 & 22 & 22 & 22 \\
\hline Mean & 9.95 & 11.84 & 9.70 & 13.23 \\
\hline SD & 1.93 & 2.10 & 2.02 & 1.56 \\
\hline :Median & 10 & 11.75 & 9.25 & 13.5 \\
\hline MIN & 6 & 7.5 & 7.5 & 10.5 \\
\hline MAX & 15 & 16 & 15 & 17 \\
\hline
\end{tabular}

Table3: Descriptive Statistics: WA Pretest and Posttest for CG and EG 


\section{LABIOD Ahlem}

Comparing the means in WA pretest shows that for the CG, the mean is 9.95 and for EG, it equals 9.70 with a minor difference. The same thing is noted for $\mathrm{SD}$, median, minimum and maximum scores. However, WA posttest results display a clear change where the mean of the CG is 11.84 and that of the EG is 13.23. Similarly, the rest of values exhibit also a considerable variance. Of course this descriptive data gives no conclusion unless it is checked statistically.

The following table is a summary of WA writing gains and $t$-test results:

\begin{tabular}{|l|c|c|c|c|c|c|c|}
\hline & \multicolumn{6}{|c|}{ WA Mean differences between CG and EG } \\
\cline { 2 - 8 } & $\mathbf{N}$ & Mean & $\begin{array}{c}\text { Std. } \\
\text { error }\end{array}$ & $\begin{array}{c}\text { std. } \\
\text { deviation }\end{array}$ & $\begin{array}{c}\text { Student- } \\
\text { t }\end{array}$ & DF & $\begin{array}{c}\text { Sig. (p- } \\
\text { value) }\end{array}$ \\
\hline Pretest & 22 & $\mathbf{- 0 . 2 5}$ & 0.596 & 1.958 & $\mathbf{- 0 . 4 1 9}$ & 42 & $\mathbf{0 . 6 6 1}$ \\
\hline Posttest & 22 & $\mathbf{1 . 3 8}$ & 0.558 & 1.960 & $\mathbf{2 . 4 8 2}$ & 42 & $\mathbf{0 . 0 0 8}$ \\
\hline
\end{tabular}

Table 4: WA Mean differences between CG and EG in Pretest and Posttest

Table 4 demonstrates that pretest WA mean difference is 0.25 . The standard error of this mean difference is 0.59 and its standard deviation is 1.95 . The tstatistic with $42 \mathrm{DF}$ is 0.41 which is a very low value. From this, we deduce that pretest WA mean difference is statistically not significant as shown by the corresponding p-value of 0.66 which is very far from 0.05 risk level. However in WA posttest, the experimental mean is higher than the control one with a difference of 1.38. This standard error of this mean difference is 0.55 and its standard deviation is 1.96 . The value t-statistic with $42 \mathrm{DF}$ is 2.48 concluding that WA posttest results are statistically significant at 0.01 risk level.

\section{Discussion}

To better discuss the pretest results for both RA and WA, the following figure presenting mean scores serves as a visual guide: 
An Integrated Reading/Writing Instruction for Better EFL Trainees at the Teachers Training School of Constantine (ENSC)

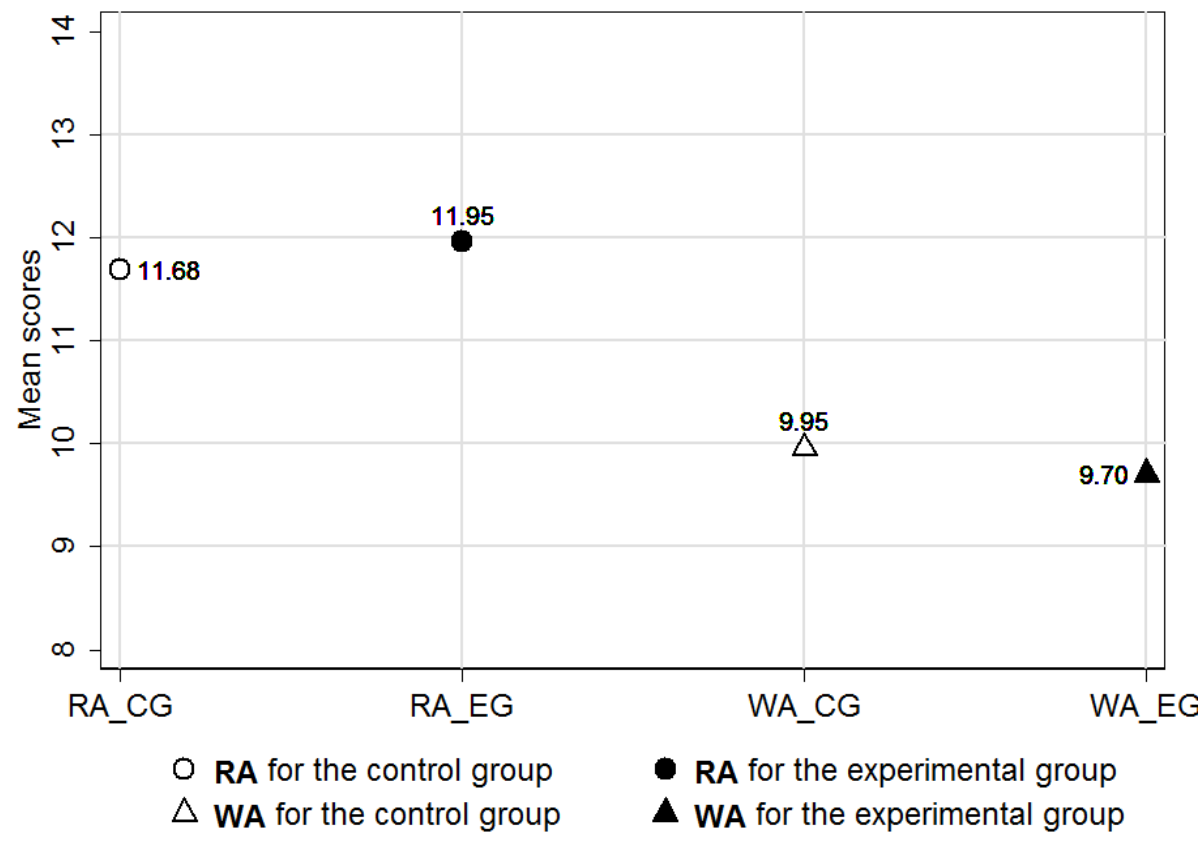

Figure 1: RA and WA Pretest Mean Scores

From the descriptive statistics and Figure 1, two main remarks are made in relation to pretest results. EG and CG scores are nearly similar in both RA and WA ensuring their homogeneous level before the experiment. Besides, learners' level, both in reading and writing, is rather an average one compared to the fact of being third-year students with normally an advanced level of proficiency. Moreover, their writing level which is below the average is a problematic fact since it constitutes a real obstacle in the whole teaching and learning process. In contrast to pretest results, posttest RA and WA increase for the EG interestingly as shown in the figure below: 


\section{LABIOD Ahlem}

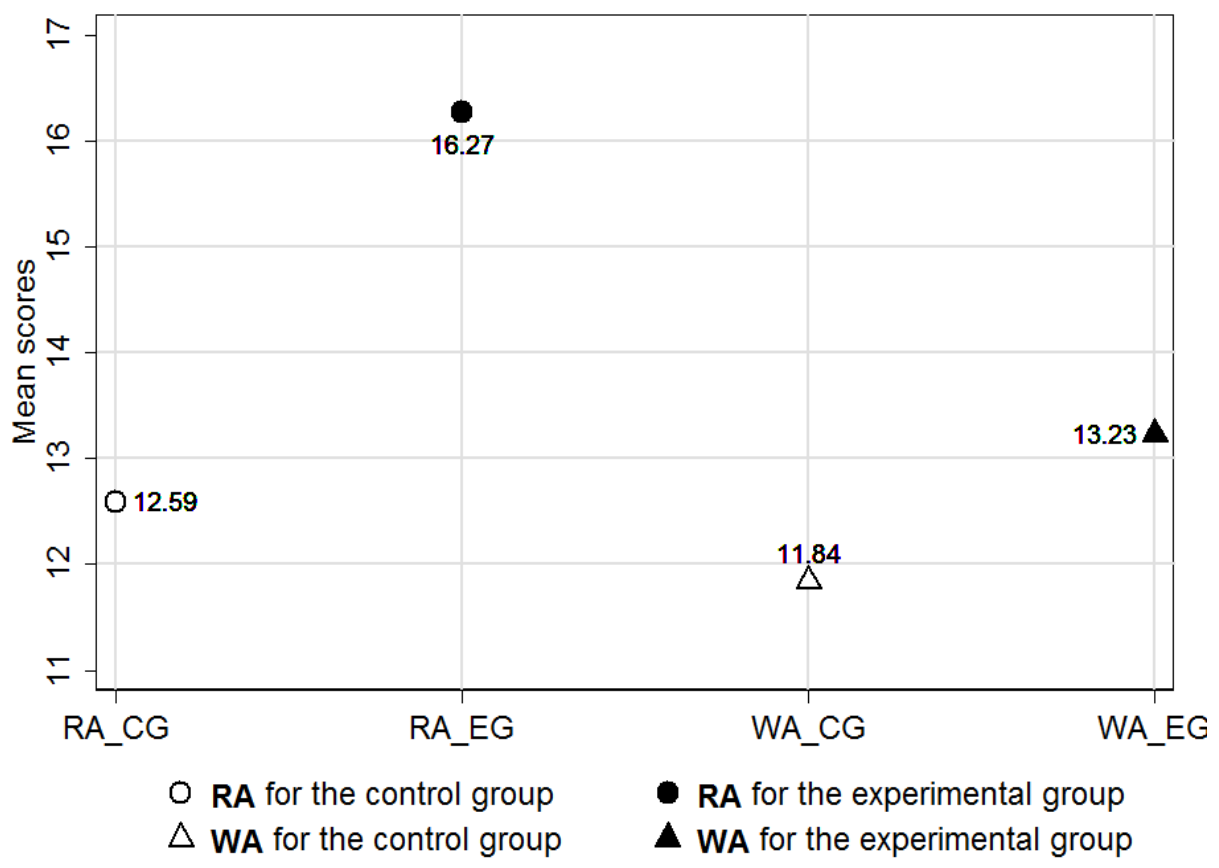

Figure 2: RA and WA Posttest Mean Scores

Figure 2 shows that the EG gained higher scores in both RA and WA posttests compared to the CG. The treatment period where experimental trainees kept writing and reading in parallel using their RRJs gave its benefits and helped learners to enhance their skills in parallel too, but the control subjects who continued to study reading and writing as discrete units failed to make a significant jump in their levels. The reason behind these positive results is that each skill served as a stimulus and reinforcement means to the other. Learners found the chance to practice reading and writing in a rather real and authentic way. Moreover, reading improvement is impressive compared to writing since at the beginning of the experiment learners started with a level difference between them. Reading seems to develop quickly compared to writing; the latter needs much more time and practice. Therefore, the implementation of an integrated reading/writing instruction through RRJs improves ENSC third-year EFL trainees' reading and writing gained scores and the study stated hypothesis is confirmed. It is never chance and randomness which lead to such positive effects in the posttest.

The study obtained results are consistent with findings from other EFL research works on reading and writing integration. Yoshimura (2009) empirical research on forty two (42) seniors and juniors majoring in English in a 


\section{An Integrated Reading/Writing Instruction for Better EFL Trainees at the Teachers Training School of Constantine (ENSC)}

Japanese University revealed that connecting reading and writing affects EFL learners' behavior positively since while writing they activate the needed schemata for reading and reading serves as an important input for writing. In addition, a micro study related to this topic of research demonstrated that a tow- month's extensive reading program had significant effects on EFL Saudi writing achievements (Almansour and Alshorman, 2014). Moreover, Elqadi and Elqadi's (2013) research on thirty (30) EFL university learners in Jordan shows significant results in paragraph-writing accuracy thanks to adopting a reading-into-writing method. Eisterhold (1990) study concludes that reading and writing are interdependent skills; the development of one leads to the development of the other and vice versa and separating them may be a hindering factor in learning English.

\section{Conclusion and Implication}

Teaching reading and writing in the EFL context of ENSC does not give the fruit teachers struggle for but trying a new instruction which integrates the two skills proves to have promising results. This article shows that the implementation of an integrated reading/writing instruction through the use of RRJs has a positive effect on learners' achievements in both skills. Although the EG improvement is reflected in higher gains compared to pretest results, these gains need to be checked qualitatively through analyzing RRJs handed back along the experiment to consolidate this quantitative conclusion.

Moreover, reconsidering the experiment's conditions is likely to give more significance to the study results. First, if the target population is enlarged to other levels and other training schools in Algeria, findings may bring further evidence about the importance of integrating the teaching of reading and writing. In addition, reading response journals, in the current paper, served as one exemplary practice and research attempts to implement the reading/writing connection poured out a variety of classroom integrated reading/writing instructional strategies in L1 drawing the path for teachers and researchers to try them in the EFL context.

To conclude, teachers as well as learners need to be aware about the importance of connecting reading and writing. However, this awareness should be transformed into a practical reality of an efficient integrated reading/writing course. One may think it logistically difficult to adopt, but innovation sometimes means an incremental change rather than a radical one. Thus, introducing firstly integrated reading/ writing workshops for both trainees and teachers is a step forward to get out of the comfort zone of traditional methods and to be less resistant to constructive innovations. The final goal then is to come to fruitful implications calling administrators, teachers and syllabus designers for curriculum revision and opting for one successful course which weds these two language skills. 
References

Almansour, N. \& Alshorman, R. (2014). The effect of an extensive program on the writing performance of Saudi EFL university students. International Journal of Linguistics, 6: 247-264

Alqadi, K. \& Alqadi, H. (2013). The effect of extensive reading on developing the grammatical accuracy of the EFL freshmen at Al-Bayt University. Journal of Education and Practice, 6: 106-113

Arciuli, J. ( 2009). Introduction to the special issues of reading and writing: "Lexical representations in reading and writing". Reading and Writing. 22( 6): 633-635

Blachowicz, C., \& Ogle, D. (2008). Reading Comprehension: Strategies for Independent Learners. New York: Guildford Press

Carlisle, A. (2000). Reading logs: An application of reader response theory in ELT. ELT Journal, 54 (1): 12-19

Dowrick, S. (2009). Creative Journal Writing: The Art and Heart of Reflection. New York: Penguin Group Inc.

Eisterhold, J. (1990). Reading/writing connections: Toward a description for second language learners. In B. Kroll (Ed.). Second Language Writing: Research Insights for the Classroom ( 88-101).Cambridge: Cambridge University Press

Evans, S. (2007). Reading reaction journals in EAP courses. ELT Journal, 62 (3): 240-247. Oxford University Press

Grabe, W. (1991). Current developments in second language reading research. TESOL Quarterly, 25 (3): 375-406

Graham, S., \& Hebert, M. A. (2010). Writing to read: evidence for how writing can improve reading. A Carnegie Corporation Time to Act Report. Washington, DC: Alliance for Excellent Education

Grambrell, L. B, Malloy, J.A, \& Mazzoni, S.A. (2007). Evidence-based best practices for comprehensive literacy instruction. In L.B, Grambrell, L. M. Morrow \& M. Pressley (Eds). Best Practices in Literacy Instruction (11-29). New York: Guilford Press

Krashen, S. (1985). Writing: Research, Theory, and Applications. New York: Pergamon Press

Kucer, B. S. (2009). Dimensions of Literacy: A Conceptual Base for Teaching Reading and Writing in School Settings. New York \& London: Routledge

Kurland, E. \& Rohr, R. (2009, May). (Truly) Integrating reading and writing in the post-secondary ESL classroom. Paper presented at M.A. TESOL conference on Cultivating Learners, Harvesting Success, San Francisco State University

Lems, K. , Miller D. L. \& Soro M.T. ( 2010). Teaching Reading to English Language Learner: Insights from Linguistics. New York: Guilford Press 
Ming-Yue, S. (2009). Reading-Writing connection for EFL college learners' literacy development. The Asian EFL Journal Quarterly. 11(1): 87-106

Rosenblatt, L. M. (2004). The transactional theory of reading and writing. In R.B, Ruddell \& N. J, Unrau (Eds). Theoretical Models and Processes of Reading, 48, 1363-1398: International Reading Association

Silberstein, S. (1994). Techniques and Recourses in Teaching Reading. London: Oxford University Press

Stotsky, S. (1983). Research on reading/writing relationships: A synthesis and suggested directions. Language Arts, 60 (5): 627-642

Yoshimura, F. (2009). Effects of connecting reading and writing and a checklist to guide the reading process on EFL learners' learning about English writing. Procedia Social and Behavioral Sciences, 1: 1871-1883

Zhou, L. \& Siriyothin, P. (2009). An investigation of university EFL students' attitudes towards writing-to-read tasks. Suranaree J. Sci. Technol, 16(4): 297-309 